\title{
Editorial
}

\section{Holding Each Other's Hands during Dark Times}

\section{Darse las manos en epocas de crisis}

\author{
Ricardo Kaempf ${ }^{1}$ Vicente Carratalá ${ }^{2}$ \\ ${ }^{1}$ Orthopedic and Traumatology Department, Santa Casa de Porto \\ Alegre, Porto Alegre, RS, Brazil \\ ${ }^{2}$ Hospital Quirónsalud Valencia, Valencia, Spain \\ Rev Iberam Cir Mano 2020;48(1):1.
}

We have been accompanying the hand surgery universe for 20 years, and we have never seen a crisis as severe as the coronavirus pandemic (COVID-19). Closed practices, suspended outpatient visits, forbidden elective surgeries, terminated rehabilitation treatments, and hand surgeons operating only emergency cases, often with no adequate protective equipment to fight an invisible and powerful enemy. No less important, the intense academic life that characterizes hand surgery has been changed with the postponement and suspension of virtually all courses and conferences.

However, adversity elicits our union and strength. We have never been so alone and so united at the same time. Crises bring opportunities, forcing us to get out of our comfort zone to create solutions to problems that otherwise would not be perceived. Instantaneous communication through social networks, in groups often exceeding one hundred participants, allows the exchange of techniques and advices on prevention and treatment routines, increasing our efficiency through this difficult moment.

The last few months witnessed a disinterested generosity from the main hand surgery societies, services and professionals, in addition to free access to top-quality scientific content, courses via webmeetings, chats and blogs with lessons and clinical case discussions that made isolation easier and more enjoyable. Free access journals, like RICMA, never have had so many accesses and such relevance as now. We at RICMA are fully committed to strengthen the fraternal bonds we already have during these hard times. It is our duty and responsibility to promote knowledge exchange and the union between our societies and colleagues from different regions, demonstrating that we can accomplish more together. When this crisis is finally over, our work will not have stopped, and we will probably be better both as individualsand professionals.

In addition, a number of physicians are disclosing their private cell phones and WhatsApp contacts so that patients can solve doubts onlineat no cost, thus avoiding unnecessary hospital visits and reducing the risk of contamination.

In Brazil, remote visits through telemedicine, which have been debated at the national congress for several months, were urgently legalized, showing that technology must be used in our favor against a powerful enemy to helpus avoid face-to-face consultations. The same has happened in many countries, where new technologies and the will of our colleagues have allowed the continuation of our work in supporting and advising our patients.

We must emphasize that,in many countries, this scenario of despair and fear resulted in fellow hand surgeons being called to be part of clinical and triage teams at the front lines against the pandemic. These professionals became true heroes for our society, and medical entities, like ours, assumed a leading role in public decisions, providing technical qualities without waiting for political actions. The general population, in turn, is recognizing all our efforts through moving demonstrations honoring our dedication and courage.

All healthcare professionals are prepared to meet social demands, thus reaffirming our role in ensuring the wellbeing of the population. Among us, who have never helped a relative, a friend, or a neighbor with guidance, advice, or prescriptions? As such, we recoverthe pride of being a physician, a feeling often forgotten by the system.

This is a delicate moment, but it brings opportunities, such as a level of commitment and unity that we have not seen for a long time. Let us hope that the lessons learned serve as teaching and bring us a better world for all citizens and physicians in the future. We demonstrate to the world that the specialty in hand surgery is strong and committed to societal demands.

We can be isolated and secluded, but we will remain united, holding each other's hands, to win this war and all those battles that are yet to come.
Address for correspondence Vicente Carratalá, PhD, Editor in Chief of RICMA, Spain (e-mail: vtecabaix@gmail.com).
DOI https://doi.org/ 10.1055/s-0040-1712094. ISSN 1698-8396.
Copyright $\odot 2020$ Thieme Revinter Publicações Ltda, Rio de Janeiro, Brazil
License terms

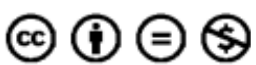

